\title{
PENGARUH PERKEMBANGAN TEKNOLOGI INFORMASI TERHADAP KEABSAHAN PERJANJIAN DALAM PERDAGANGAN SECARA ELEKTRONIK (E-COMMERCE) DI ERA GLOBALISASI
}

\author{
Lathifah Hanim \\ Fakultas Hukum Universitas Islam Sultan Agung Semarang \\ E-mail: lathifah.hanim@yahoo.com
}

\begin{abstract}
Economic activity in the entire world with the existence of existence is increasingly dependent telematic technology. The development of Information technology giving influence on the validity of contracts in electronic commerce (E-Commerce) in the era of globalization and the what's factors constraints on the validity of contracts in electronic commerce (E-Commerce) in the era of globalization. Article 1320 Civil Code is the principal instrument to test the validity of contracts made by the parties. Article 1320 Civil Code there are four legal conditions of contract, namely: agreements, the ability to create engagement, a certain thing, and a lawful reason. Contracts that do not meet the agreement and skill, resulting in the contract to cancel and void by law, if there are contracts that do not qualify or do not have a specific object or cause is not allowed, the resulting contract is null and void.
\end{abstract}

Keywords: E-commerce, validity of agreement

\begin{abstract}
Abstrak
E-commerce mampu mempertemukan antara penjual dan pembeli dari seluruh dunia dan melakukan transaksi jual beli hanya dari belakang komputer. Teknologi informasi memberi pengaruh terhadap keabsahan perjanjian dalam perdagangan secara elektronik (E-Commerce) pada era globalisasi dan faktor-faktor apa sajakah yang menjadi kendala terhadap keabsahan perjanjian dalam perdagangan secara elektronik (E-Commerce) pada era globalisasi. Pasal 1320 KUHPerdata merupakan instrumen pokok untuk menguji keabsahan kontrak yang dibuat para pihak. Pasal 1320 KUHPerdata ada empat syarat sahnya suatu kontrak, yaitu :kesepakatan, kecakapan untuk membuat perikatan, suatu hal tertentu ,dan suatu sebab yang halal. Kontrak yang tidak memenuhi kesepakatan dan kecakapan, berakibat kontrak tersebut dapat di batalkan dan batal demi hukum, apabila terdapat kontrak yang tidak memenuhi syarat objek tertentu atau tidak mempunyai causa atau causanya tidak diperbolehkan, berakibat kontrak tersebut batal demi hukum.
\end{abstract}

Kata Kunci : E-commerce dan keabsahan perjanjian

Pendahuluan

Konvergensi teknologi informasi dan telekomunikasi telah mengakibatkan beragamnya fasilitas telekomunikasi dan canggihnya produk teknologi informasi yang mampu mengintegrasikan semua media informasi. Di tengah globalisasi komunikasi yang semakin terpadu (global communication network) ini, internet menjadi populer dan membuat dunia semakin menciut (shrinking the world) sekaligus memudarkan batas negara berikut kedaulatan dan tatanan masyarakatnya. ${ }^{1}$ Kemajuan teknologi telah membawa perubahan dan pergeseran yang cepat dalam suatu kehidupan tanpa batas di era globalisasi ini. Globalisasi merupakan proses penghapusan berbagai kendali yang menghalangi gerak kinerja perdagangan dan modal untuk merentangkan jangkauan seluas bola dunia. $^{2}$

Arsyad Sanusi, "Efektivitas UU ITE dalam Pengaturan Perdagangan Elektronik (E-Commerce)", Jurnal Hukum Bisnis, 29 (1), 2010, hlm. 5

2 Herry Priyono, Marginalisasi ala Neoliberalisme, Majalah BASIS, No. 05 - 06, Tahun ke-53, Mei - Juni 2004, hal. 15; Joko Susanto, "Kajian Teoritik Tentang Penga- 
Pemanfaatan teknologi telah mendorong pertumbuhan bisnis yang pesat, karena berbagai informasi dapat disajikan melalui hubungan jarak jauh dan mereka yang ingin mengadakan transaksi tidak harus bertemu muka, akan tetapi cukup melalui peralatan komputer dan telekomunikasi. Perkembangan teknologi informasi juga membentuk masyarakat dunia baru yang tidak lagi dihalangi oleh batas-batas teritorial dan telah membalikkan segalanya yang jauh jadi dekat yang khayal jadi nyata. Internet dan teknologi informasi merupakan inovasi baru pada dekade terakhir ini yang mempengaruhi kehidupan manusia. Beberapa aktifitas manusia berubah secara signifikan dengan mengambil keuntungan dari efisiensi, efektifitas dan mobilitas. Sayangnya, kemajuan teknologi ini juga memperkenalkan permasalahan-permasalahan baru saat digunakan secara tidak tepat atau menyalahi dari yang semestinya. Kejahatan Cyber (Cyber-crime) adalah bentuk ancaman baru yang belum pernah ada sebelumnya pada masyarakat dunia. Hacking, Cracking, Defacing, Sniffing, Carding, Phising, Spaming, Scam adalah sederet kejahatan internet yang cukup berbahaya dan telah menimbulkan kerugian nyata pada banyak pihak.

Saat ini telah lahir suatu rezim hukum ba-ru yang dikenal dengan Hukum Cyber. Istilah "hukum cyber" diartikan sebagai padanan kata dari Cyber Law, yang saat ini secara internasional digunakan untuk istilah hukum yang terkait dengan pemanfaatan teknologi informasi. Istilah lain yang juga digunakan adalah hukum Teknologi Informasi (Law of Information Technology), Hukum Dunia Maya (Virtual World Law) dan Hukum Mayantara. Istilah-istilah tersebut lahir mengingat kegiatan internet dan pemanfaatan teknologi informasi berbasis virtual.

Kegiatan cyber meskipun bersifat virtual dapat dikategorikan sebagai tindakan dan perbuatan hukum yang nyata. Secara yuridis dalam hal ruang cyber sudah tidak pada tempatnya lagi untuk mengkategorikan sesuatu dengan ukuran dan kualifikasi hukum konvensional un-

ruh Globalisasi Terhadap Proses Demokratisasi”, Masyarakat, Kebudayaan dan Politik, Th XIII, No 2, April 2000, 59-72. tuk dapat dijadikan objek dan perbuatan, sebab jika cara ini yang ditempuh akan terlalu banyak kesulitan dan hal-hal yang lolos dari jerat hukum. Kegiatan cyber adalah kegiatan virtual yang berdampak sangat nyata meskipun alat buktinya bersifat elektronik. Dengan demikian subjek pelakunya harus dikualifikasikan pula sebagai orang yang telah melakukan perbuatan hukum secara nyata.

Selama ini, terutama di kalangan yuris, ada kecenderungan atau setidaknya kesan untuk mengedepankan aspek hukum dalam se-tiap pembahasan upaya penanggulangan keja-hatan berteknologi tinggi. Dalam menghadapi merebaknya cyber crime di Indonesia, misalnya, selalu saja yang disebut-sebut kegagalan dalam mengungkap para pelaku adalah karena masih minim dan belum sempurnanya cyber law di Indonesia. Sementara aspek lain seperti sosial, ekonomi, politik dan budaya hampir ti-dak pernah digarap. Padahal dalam khasanah penanggulangan terdapat politik kriminal yang menempatkan pendekatan nonpenal pada posisi yang strategis.

Pemerintah memandang Undang-undang tentang Informasi dan Transaksi Elektronik (ITE) mutlak diperlukan bagi negara Indonesia, karena saat ini Indonesia merupakan salah satu negara yang telah menggunakan dan memanfaatkan teknologi informasi secara luas dan efisien. Sehingga pemrintah pada tanggal 26 April 2008 mensahkan berlakunya UU ITE. UU ITE dimaksudkan dapat memberikan banyak manfaat,diantaranya untuk menjamin kepastian hukum bagi masyarakat yang melakukan transaksi elektronik, mendorong pertumbuhan ekonomi, mencegah terjadinya kejahatan berbasis teknologi informasi dan melindungi masyarakat pengguna jasa dengan memanfaatkan teknologi informasi.

Pembentukan UU ITE adalah sebagai wujud "Pembaharuan Hukum" sebagai pengaruh dari 7 (tujuh) aspek pembaharu hukum, yaitu aspek ilmu pengetahuan dan teknologi, yang sebagaimana diketahui delapan aspek pembaharu hukum antara lain, aspek globalisasi, aspek politik, aspek ekonomi, aspek pendidikan, aspek ilmu penge-tahuan dan teknologi, aspek 
supremasi hukum dan aspek perspektif hukum Islam. Undang-undang tentang Informasi dan Transaksi Elektronik dibentuk dalam upaya mengimbangi perkembangan ilmu pengetahuan dan teknologi di bidang teknologi informasi dan transaksi elektronik, agar tidak terjadi kekosongan hukum jika terjadi tindakan perbuatan melawan hukum. ${ }^{3}$

E-commerce mampu mempertemukan antara penjual dan pembeli dari seluruh belahan dunia dan melakukan transaksi jual beli hanya dari belakang komputer yang terkoneksi dengan jaringan internet. Demikian pula dengan teknologi EFT (Electronic Funds Transfer) maka pengiriman uang antar pelaku ekonomi yang berada pada belahan dunia yang berjauhan dapat dilakukan dengan hitungan detik. Perkembangan transaksi e-commerce menunjukkan adanya peningkatan yang sangat signifikan, tidak saja di negara-negara maju tetapi juga di negara berkembang, khususnya Indonesia. ${ }^{4}$ Berdasarkan latar belakang tersebut, penulis tertarik untuk membahas mengenai bagaimana legalitas perjanjian dalam perdagangan secara elektronik (E-Commerce) pada era globalisasi dan unsur apa saja yang menjadi hambatan untuk menentukan keab-sahan perjanjian dalam perdagangan secara elektronik (ECommerce).

\section{Pembahasan Masalah}

Legalitas Perjanjian dalam Perdagangan secara Elektronik (E-Commerce) pada Era Globalisasi.

Karakteristik perkembangan teknologi informasi ditandai dengan tanda-tanda berikut: kecepatan, kapasitas, keterpaduan, kemudahan, kemampuan, jangkauan, serta keterbukaan. Beberapa perubahan terjadi, misalnya dalam bilangan MIPS (jutaan instruksi perdetik) berganti menjadi GIPS (miliar instruksi per detik), bahkan perkembangan terus menjadi GFLOPS

3 Ermansiah Djaja, 2010, Penyelesaian Sengketa Teknologi Infomasidan Transaksi Elektronik (Kajian Yuridis Penyelesaian Secara NonLitigasi melalui Arbitrase dan Alternatif Penyelesaian Sengketa), Yogyakarta : Pustaka Timur, hlm. ix.

4 Bagus Hanindyo Mantri, "Perlindungan Hukum terhadap Konsumen dalam Transaksi E-commerce", Jurnal MMH, edisi 37 No. 4, Desember 2008, hlm. 273 (miliaran operasi floating point per detik). Dalam bidang kecepatan (speed), transmisi intra dan antar sistem semakin cepat dengan menggunakan super konduktor dan serat optik.

Teknologi komputer berhasil mengkonvergensikan berbagai teknologi digital dan media elektronika menjadi apa yang populer disebut telematika. Teknologi internet telah membuat perusahaan melakukan beberapa aktivitas bisnis seperti online marketing, distance selling, dan e-commerce.

Sebelum membahas e-commerce yang menggunakan jasa internet, perlu pemahaman tentang arti internet. Internet diartikan An international network of computers that provide a wide variety of communication and information retrieval methods to all those with access to the internet. This includes electronic mail, automatic mailing list services, news group, chat rooms, the world wide web (yang secara keseluruhan membentuk suatu medium yang disebut cyber space $)^{5}$

Cakupan e-commerce menurut World Trade Organization (WTO), cakupan e-commerce meliputi bidang produksi, distribusi, pemasaran, penjualan, pengiriman barang atau jasa melalui cara elektronik, sedangkan menurut $\mathrm{OECD}^{6}$ (organization for Economic Cooperation and Development), bahwa e-commerce adalah transaksi berdasarkan proses dan transmisi data secara elektronik. Selain dari dua lembaga internasional tersebut, Alliance for Global Business, suatu asosiasi di bidang perdagangan terkemuka mengartikan e-commerce sebagai seluruh transaksi nilai yang melibatkan transfer informasi, produk, jasa atau pembayaran melalui jaringan elektronik sebagai media. Dengan melalui media inilah transaksi bisnis dapat berlangsung dari mulai pengiklanan, penginventarisasian, perancang-

Hata, Pengertian Internet Menurut Supreme Court Amerika, dalam makalah seminar cyber law di STHB Bandung pada tanggal 9 April 2001; Lihat Bayu Seto Hardjowahono, "Asas-asas Hukum Perdagangan Internasional Otonom dan Upaya Harmonisasi Hukum Kontrak Internasional Regional di Kawasan Asean", Jurnal Hukum Pro Justitia, Vol. 26 No. 3, Juli 2008 FH Unpar Bandung, hlm. 191-197;

6 Lihat Dahliana Hasan, "The Impact of E-Commerce on Cross Border Taxation”, Jurnal Mimbar Hukum Vol. 18 No. 1, Februari 2006, FH UGM Yogyakarta, hlm. 74-76 
an, pembuatan katalog, transaksi dan pengiriman barang. ${ }^{7}$

Beberapa upaya internasional dalam memformulasikan aturan yang berkaitan dengan e-commerce telah dimulai oleh beberapa organisasi internasional seperti UNCTAD, UNCITRAL, OECD dan WTO. ${ }^{8}$ United Nation Conference on Trade and Development (UNCTAD) sebagai salah satu badan PBB yang concern dalam bidang perdagangan dan pembangunan negara-negara dunia ketiga telah memberikan respons yang progresif dalam hal menyikapi perdagangan bebas, terutama yang berbasiskan internet. Upaya-upaya tersebut adalah sebagai berikut mendirikan Global Trade Point Network (GTP Net), yang bertujuan membantu negara berkembang dalam usaha mendapatkan manfaat serta akses di bidang komunikasi elektronik; pendirian TPDC (the Trade Point Development (entre) yang dibentuk oleh Mel-bourne Insti-tute of Technology, ETOS (The Electronic Trading Opportunities). Pada dasarnya, pendirian provider di bidang komunikasi internet untuk perdagangan internasional tersebut diarahkan untuk memfasilitasi transaksi bisnis (from contact to contract), artinya berawal dari kontrak/hubungan via internet melahirkan suatu kontrak atau transaksi antar pengakses.

OECD (Organization for Economic Cooperation and Development), upaya-upaya yang telah dilakukan adalah implikasi e-commerce terhadap berbagai hal, diantaranya frame work atau kerangka kebijakan umum, ekonomi informasi, isi, keamanan, privasi, kriptografi, kemudian akses, kebijakan telekomunikasi, perusahaan kecil dan menengah, kebijakan mengenai konsumen, perpajakan dan pariwisata.

7 Rizal Alif, "Persprektif Transaksi Decommerce di era Globalisasi Perdagangan Bebas dalam Hukum Perjanjian di Indonesia", Jurnal hukum Internasional, Vol. 5 No. 2, Januari 2008, hlm. 347; Iriansyah, "Pembayaran Dalam Transaksi Perdagangan Internasional”, Jurnal Hukum Respublica, Vol. 3 No. 2, Igm. Sumarsono Raharjo, "Pentingnya Perlindungan Hukum Informasi Elektronik dalam Transaksi Online", Justitia Et Pax, Vol. 26 No. 1, Juni 2006, hlm. 186; 62-67; Wenny Setiawati, "Elektronic Commerce in The International Trade and The Impact on Indonesia", Jurnal Hukum dan Pembangunan Tahun ke-38 No. 3, Juli-September 2008 FH UI Jakarta, hlm. 317-324

8 Hata, Op.cit.
United Nations Commission on International Trade law (UNCITRAL), yang merupakan salah satu badan PBB yang bergerak dalam perdagangan internasional memandang isu $e$ commerce ini merupakan suatu mendesak untuk segera dirumuskan rules of law-nya. Dewasa ini, issu e-commerce masih dalam wacana akademik, khususnya di Indonesia dan belum ada pengaturannya melalui undang-undang. $\mathrm{Pa}$ da saat ini, transaksi melaui $e$-commerce belum diatur secara khusus, baik dalam undangundang maupun konvensi inter-nasional, namun UNCITRAL telah melakukan beberapa upaya merumuskan UNCITRAL Model Law on Electronic Commerce. Model law ini telah disepakati pada tahun 1996 dan diadakan tambahan berupa pasal 5 bis pada tahun $1998 .{ }^{9}$ Model law yang dipersiapkan oleh UNCITRAL adalah untuk merespons dan mengantisipasi terhadap teknikteknik bisnis modern dengan menggunakan komunikasi elektronik yang berbasiskan internet. Model law yang diajukan oleh UNCITRAL terdiri dari dua bagian, yaitu bagian I adalah e-commerce pada umumnya (Pasal 1 sampai dengan Pasal 15) dan Bagian II e-commerce dan bidangbidang khusus (Pasal 16 sampai Pasal 17).

World Trade Organization (WTO), merupakan organisasi perdagangan dunia yang telah secara aktif menyoroti perkembangan $e$ commerce dalam dunia bisnis menyatakan bahwa secara signifikan $e$-commerce telah menunjukkan kenaikan nilai transaksi, di mana pada tahun 1990 belum ada aktifitas yang menggunakan e-commerce, namun pada tahun 2001 telah menunjukkan nilai transaksi yang berarti, yakni mencapai nilai US 300 miliar. Selain mengikuti nilai transaksi yang dihasilkan dari $e$ commerce. WTO mencatat di mana pada tahun 1997 pengguna internet baru mencapai 78 juta dan pada tahun 2000 telah mencapai 280 juta pengguna (netter) atau sekitar $5 \%$ penduduk dunia, bahkan diprediksikan pada tahun 2008 angka tersebut akan mencapai 50\%. Dengan hadirnya e-commerce sebagai alternatif praktis, efisien, cepat dan akurat akan menimbulkan

\footnotetext{
Tim Direktorat Hukum, "Diskusi Dengan Uncitral Dan "Electronic Evidence \& E-Discovery Forum", Buletin Hukum Perbankan Dan Kebanksentralan, Volume 5, Nomor 2, Agustus 2007, hlm. 49-52
} 
perubahan policy/kegiatan industri, termasuk industri asuransi, perbankan, jasa peran-tara, travel biro, telekomunikasi, periklanan, serta industri yang menyediakan pelayanan medis dan pendidikan. Dalam sektor publik sekalipun, akan memberikan suatu solusi yang tepat dalam pelayanan jasa pemerintahan dan investasi. Dalam menyikapi e-commerce, WTO dengan sejumlah organ di dalamnya melakukan penelitian, di antaranya Committee for Trade and Development dan Council for Trade Related Aspects of Intellectual Property Rights.

E-commerce semakin populer dalam bisnis yang berbasiskan informasi, namun bukan berarti e-commerce tidak mempunyai kelemahan. Tidak jarang terjadinya pemalsuan identitas, pembobolan password pemilik kartu kredit atau dikenal dengan carding untuk mengorder suatu produk, padahal yang bersangkutan tidak memiliki sepeser pun rekening bank. Untuk menunjang e-commerce yang trustable atau dapat dipercaya memerlukan beberapa hal. Pertama, authenticity; menyangkut kebenaran jati diri seseorang, misalnya bahwa di Andi adalah benar-benar si Andi; kedua, integrity; menyangkut kebenaran isi pesan misalnya dalam pesan dinyatakan bahwa yang ditransfer adalah benar Rp.10.000.000,- bukan Rp.100. 000.000,-; ketiga, non-repudiation; menyangkut pembuktian sebuah tindakan bahwa si Andi telah melakukan kesepakatan dengan orang lain sebagaimana tercantum dalam dokumen kesepakatan yang telah di sepakati; keempat, confidentiality; menyangkut kerahasiaan, yaitu di mana sebuah pesan tidak bisa terbaca oleh orang lain, apabila sekalipun terbaca dan diubah, maka si penerima pesan mengetahui bahwa telah terjadi perubahan dan dengan demikian mencegah terjadinya kerugian. ${ }^{10}$ Namun demikian, perlu diperhatikan pula bahwa keberhasilan hukum dalam memainkan peranan dalam pembangunan ekonomi, seperti di negara-negara maju, justru tidak sesederhana yang dialami oleh negara berkembang. Hal ini disebabkan masih kuatnya isu-isu klasik seperti

10 Indra M.Utoyo, Public Key, makalah Seminar Nasional Cyber law "Infrastruktur dan Kebutuhan Dukungan Aspek Hukumnya dalam Implementasi Tandatangan Digital", SHTB Bandung, 9 April 2001; rendahnya tingkat kesejahteraan dan pendidikan. ${ }^{11}$

Unsur yang Menjadi Hambatan terhadap Keabsahan Perjanjian secara Elektronik (E-Commerce)

Perjanjian adalah suatu perbuatan dengan mana satu orang atau lebih mengikatkan dirinya terhadap satu orang atau lebih (Pasal 1313 KUHPerdata). Perjanjian melahirkan hak dan kewajiban antara dua pihak (Pasal 1233 KUHPerdata), hak dan kewajiban tersebut dinamakan dengan perikatan-perikatan.

Perikatan adalah hubungan hukum antara dua pihak, dimana satu pihak ada hak dan dilain pihak ada kewajiban. Isi atau prestasi dari perikatan harus bisa dijabarkan. Prestasi bisa dalam bentuk memberikan sesuatu, untuk berbuat sesuatu atau untuk tidak berbuat sesuatu.

Unsur-unsur dari perjanjian adalah unsur essentialia yaitu bagian daripada perjanjian yang tanpa itu perjanjian tidak mungkin ada, misalnya: harga dalam perjanjian jual beli, unsur naturalia yaitu bagian yang oleh undangundang ditentukan sebagai peraturan yang bersifat mengatur, misalnya: Penanggungan, dan unsur accidentalia yaitu bagian-bagian yang oleh para pihak ditambahkan dalam perjanjian dimana undang-undang tidak mengaturnya, misalnya: jual beli rumah beserta perabotnya.

Terdapat 4 (empat) syarat syahnya perjanjian (Pasal 1320 KUHPerdata), yaitu: sepakat mereka yang mengikatkan dirinya, kecakapan untuk membuat suatu perikatan, suatu hal tertentu dan suatu sebab yang halal. Syarat pertama untuk sahnya suatu perjanjian adalah harus adanya "sepakat mereka yang mengikatkan dirinya". Kesepakatan, artinya kedua belah pihak dalam suatu perjanjian harus mempunyai kemauan yang bebas untuk mengikatkan diri dan kemauan itu harus dinyatakan, dan pernyataan itu dapat dilakukan dengan tegas atau secara diam-diam.

\footnotetext{
11 Taufik H Simatupang, "Hukum dan Pembangunan Ekonomi”, Jurnal Ilmiah Kebijakan Hukum, Vol. 1 No. 1, April 2007, hlm. 20
} 
Syarat kedua untuk sahnya suatu perjanjian adalah adanya "kecakapan untuk membuat suatu perjanjian". Arti kecakapan adalah kewenangan untuk melakukan tindakan hukum pada umumnya, dan menurut hukum setiap orang adalah cakap untuk membuat perjanjian kecuali orang-orang yang menurut undang-undang dinyatakan tidak cakap. Kualifikasi sebagai orang tidak cakap membuat suatu perjanjian adalah orang-orang yang belum dewasa, mereka yang ditaruh di bawah pengampuan dan perempuan yang telah kawin. Orang yang belum dewasa adalah mereka yang belum genap berumur 21 tahun dan tidak telah kawin. Dengan demikian dewasa adalah mereka yang telah berumur 21 tahun dan telah kawin.

Pasal 330 KUHPerdata mengatur bahwa seseorang yang berumur di bawah 21 tahun tetapi sudah kawin dianggap telah dewasa menurut hukum. Orang yang ditaruh di bawah pengampuan, adalah orang-orang yang dalam penyelenggaraan kepentingannya diurus dan diwakili oleh orang lain (orang tua, wali, curator). Orang-orang yang ditaruh di bawah pengampuan menurut Pasal 433 KUHPerdata adalah setiap orang dewasa yang selalu dalam kadaan gila, dungu, lemah akal walaupun jika ia kadang-kadang cakap mempergunakan pikirannya dan seseorang dewasa yang boros.

Akibat hukum apabila orang yang tidak cakap membuat suatu perjanjian, maka perjanjian tersebut dapat dibatalkan atas tuntutan si tidak cakap atau oleh wakilnya. Akibat hukum dari pembatalan perjanjian akibat salah satu pihak tidak cakap adalah para pihak dipulihkan dalam keadaan seperti sebelum perjanjian dibuat dan hal-hal yang telah diperjanjikan/diserahkan harus dikembalikan.

Syarat ketiga untuk sahnya suatu perjanjian adalah harus adanya "suatu hal tertentu". Arti dari "suatu hal tertentu" adalah suatu hal tertentu berarti yang diperjanjikan dalam suatu perjanjian haruslah suatu hal atau suatu barang yang cukup jelas atau tertentu yakni paling sedikit ditentukan jenisnya. Contohnya jual beli beras dalam gudang. Hanya barang-barang yang dapat diperdagangkan saja yang dapat menjadi pokok suatu perjanjian.
Syarat keempat untuk sahnya suatu perjanjian adalah harus adanya "suatu sebab yang halal". Artinya apa yang hendak dicapai oleh kedua belah pihak dengan mengadakan perjanjian itu. Dimana dilarang untuk membuat perjanjian tanpa tujuan bersama, atau yang dibuat karena sesuatu sebab yang palsu atau terlarang. Akibatnya jika suatu perjanjian dibuat tanpa adanya hal tertentu dan tanpa suatu sebab yang halal, maka perjanjian tersebut batal demi hukum.

Semua transaksi e-commerce yang memenuhi syarat Pasal 1320 KUHPerdata diakui sebagai perjanjian dan mengikat bagi para pihak. Pasal ini terkait juga dengan Pasal 1337 KUHPerdata yang menyangkut Kuasa yang dilarang (bertentangan dengan kesusilaan dan ketertiban umum). Dalam transaksi e-commerce di mana para pihak tidak bertemu secara langsung unsur kecakapan menjadi suatu persoalan tersendiri karena seringkali para pihak tidak mengetahui kecakapan lawan kontraknya termasuk umur/kedewasaan. Seperti yang diatur dalam Pasal 1330 tentang kedewasaan.

Perbuatan melanggar hukum, yang membawa kerugian kepada seorang lain, mewajibkan orang yang karena salahnya menerbitkan kerugian itu, mengganti kerugian tersebut. Para pihak yang dirugikan dalam transaksi $e$ commerce tetapi unsur itu tidak diatur dalam perjanjian tetap dapat menggunakan Pasal 1365 untuk pengajuan gugatan.

Setiap orang yang mendalilkan bahwa ia mempunyai sesuatu hak, atau guna meneguhkan haknya sendiri maupun membantah suatu hak orang lain, menunjuk pada suatu peristiwa, diwajibkan membuktikan adanya hak atau peristiwa tersebut. Pasal ini perlu di harmonisasikan atau direvisi jika dikaitkan dengan transaksi e-commerce karena akan sangat menyulitkan pihak yang tidak menguasai teknologi sebagai contoh nasabah bank yang dirugikan melalui transaski ATM.

Perjanjian yang dibuat secara sah berlaku sebagai undang-undang bagi mereka yang membuatnya. Suatu perjanjian tidak dapat ditarik kembali selain dengan sepakat kedua belah pihak, atau karena alasan-alasan yang oleh undang-undang dinyatakan cukup untuk itu. 
Suatu perjanjian harus dilaksanakan de-ngan itikad baik. Asas kebebasan berkontrak juga merupakan dasar transaksi e-commerce sehingga kontrak yang dibuat akan mengikat sebagai layaknya suatu undang-undang bagi pembuatnya. ${ }^{12}$

Perlu dikaji lebih lanjut tentang kemungkinan pengakuan otentisasi akta-akta elektronik melalui suatu mekanisme cyber notary. Perlu juga memfungsikan CA dalam pembuktian tulisan dari akta elektronis. Pembuktian dengan tulisan dilakukan dengan tulisan otentik maupun dengan tulisan-tulisan di bawah tangan.

Menyikapi tuntutan dinamika tersebut di atas, pembuat undang-undang telah menyiapkan seperangkat aturan hukum sebagai tolak ukur bagi para pihak untuk menguji standar keabsahan kontrak yang mereka buat. Perangkat aturan hukum tersebut diatur dalam sistematika Buku III KUHPerdata, yaitu syarat sahnya kontrak yang diatur dalam Pasal $1320 \mathrm{KUH}$ Perdata, dan syarat sahnya kontrak yang diatur di luar Pasal 1320 KUHPerdata (vide Pasal 1335, Pasal 1337, Pasal 1339 dan Pasal 1347).

Pasal 1320 KUHPerdata merupakan instrumen pokok untuk menguji keabsahan kontrak yang dibuat para pihak. Dalam Pasal 1320 KUHPerdata tersebut terdapat empat syarat yang harus dipenuhi untuk sahnya suatu kontrak, yaitu Sepakat mereka mengikatkan dirinya (de toestemming van degenendie zich verbinden), kecakapan untuk membuat perikatan (de bekwaamheid om eene verbintenis aan te gaan) dan suatu hal tertentu (een bepaald onderwerp) suatu sebab yang halal atau diperbolehkan (eene geoorloofde oorzaak).

Sistem common law untuk sahnya suatu kontrak juga mensyaratkan dipenuhinya beberapa elemen. Secara garis besar elemen penting pembentuk kontrak, meliputi: Pertama, Intention to create a legal relationship, para pihak yang berkontrak memang bermaksud bahwa kontrak yang mereka buat dapat dilaksanakan berdasarkan hukum; Kedua, Agreement (offer and acceptance), artinya harus ada ke-

12 Harry Purwanto, "Keberadaan Asas Pacta Sunt Servanda Dalam Perjanjian Internasional", Mimbar Hukum Vol. 21 No. 1, Februari 2009, hlm. 160-164 sepakatan (meeting of mind) diantara para mereka; Ketiga, Consideration, merupakan janji di antara para pihak untuk saling berprestasi.

M.L.Barron ${ }^{13}$ menambahkan elemen pembentuk kontrak, selain ketiga di atas, meliputi juga Capacity of parties, kecakapan para pihak; Reality of consent, artinya harus benarbenar kesepakatan yang sesuai dengan kehendaknya, bukan karena adanya cacat kehendak (misrepresentation, duress or undue influence); dan Legality of object (terkait dengan tujuan atau objek yang harus diperbolehkan menurut hukum).

Suatu kontrak yang tidak memenuhi syarat sah sebagaimana yang diatur dalam Pasal 1320 KUHPerdata, baik syarat subyektif mau pun syarat obyektif akan mempunyai akibat sebagai berikut: Pertama, noneksistensi, apabila tidakada kesepakatan maka tidak timbul kontrak. Kedua, Vernietigbaar atau dapat dibatalkan, apabila kontrak tersebut lahir karena adanya cacat kehendak (wilsgebreke) atau karena ketidakcakapan (onbekwaamheid) - Pasal 1320 KUHPerdata syarat 1 dan 2), berarti hal initerkait dengan unsur subjektif, sehingga berakibat kontrak tersebut dapat di batalkan; dan Ketiga, Nietig atau batal demi hukum, apabila terdapat kontrak yang tidak memenuhi syarat objek tertentu atau tidak mempunyai causa atau causanya tidak diperbolehkan (Pasal 1320 KUHPerdata syarat 3 dan 4), berarti hal ini terkait dengan unsur subyektif, sehingga berakibat kontrak tersebut batal demi hukum.

Konsep atau strategi terhadap keabsahan perjanjian dalam perdagangan secara elektronik (E-Commerce) di era globalisasi, untuk menunjang e-commerce yang trustable atau dapat dipercaya memerlukan beberapa hal, yaitu authenticity; menyangkut kebena-ran jati diri seseorang, integrity; menyangkut kebenaran isi pesan, Non-repudation; menyangkut pembuktian sebuah tindakan, confidentiality; menyangkut kerahasiaan, yaitu di mana sebuah

13 Barron memberikan akronim untuk keseluruhan elemen kontrak tersebut dengan istilah "FROLIC" yaitu F (form and/or consideration); R (reality of consent); 0 (offer and acceptance); L (legality of object); I (intention to create a legal relationship); C (capacity of parties). M.L. Barron,1998, Fundamentals of Business Law, McGraw-Hill Book Co, Sydney, hlm.146-147. 
pesan tidak bisa terbaca oleh orang lain, apabila sekalipun terbaca dan diubah, maka si penerima pesan mengetahui bahwa telah terjadi perubahan dan dengan demikian mencegah terjadinya kerugian.

\section{Penutup}

Simpulan

Perkembangan teknologi informasi terhadap keabsahan perjanjian dalam perdagangan secara elektronik (E-Commerce) di era globalisasi adalah semua transaksi e-commerce yang memenuhi syarat Pasal 1320 KUHPerdata diakui sebagai perjanjian dan mengikat bagi para pihak. Dalam transaksi e-commerce di mana para pihak tidak bertemu secara langsung unsur kecakapan menjadi suatu persoalan tersendiri, seringkali para pihak tidak mengetahui kecakapan lawan kontraknya termasuk umur/kedewasaan.

Unsur yang menjadi kendala dalam perkembangan teknologi informasi terhadap keabsahan perjanjian dalam perdagangan secara elektronik (E-Commerce) adalah tidak jarang terjadinya pemalsuan identitas, pembobolan password pemilik kartu kredit atau dikenal dengan carding untuk mengorder suatu produk, padahal yang bersangkutan tidak memiliki sepeser pun rekening bank.

\section{Daftar Pustaka}

Sanusi, Arsyad. "Efektivitas UU ITE dalam Pengaturan Perdagangan Elektronik (E-Commerce)", Jurnal Hukum Bisnis. Vol. 29 No. 1. 2010;

Priyono,Herry. "Marginalisasi ala Neoliberalisme". Majalah BASIS. No. 05 - 06, Tahun ke-53, Mei - Juni 2004;

Susanto, Joko. "Kajian Teoritik Tentang Pengaruh Globalisasi Terhadap Proses Demokratisasi". Masyarakat, Kebudayaan dan Politik. Th. 13. No 2. April 2000;

Djaja, Ermansiah. 2010. Penyelesaian Sengketa Teknologi Infomasi dan Transaksi Elektronik (Kajian Yuridis Penyelesaian Secara NonLitigasi melalui Arbitrase dan Alternatif Penyelesaian Sengketa). Yogyakarta : Pustaka Timur;

Mantri, Bagus Hanindyo. "Perlindungan Hukum terhadap Konsumen dalam Transaksi E- commerce". Jurnal MMH. edisi 37 No. 4. Desember 2008;

Hata. 2001. "Pengertian Internet Menurut Supreme Court Amerika", makalah dalam seminar cyber law di STHB Bandung pada tanggal 9 April;

Hardjowahono, Bayu Seto. "Asas-asas Hukum Perdagangan Internasional Otonom dan Upaya Harmonisasi Hukum Kontrak Internasional Regional di Kawasan Asean". Jurnal Hukum Pro Justitia. Vol. 26 No. 3. Juli. 2008. Bandung: FH Unpar;

Hasan, Dahliana. "The Impact of E-Commerce on Cross Border Taxation". Jurnal Mimbar Hukum Vol. 18 No. 1. Februari. 2006. Yogyakarta: FH UGM;

Alif, Rizal "Persprektif Transaksi Decommerce di era Globalisasi Perdagangan Bebas dalam Hukum Perjanjian di Indonesia". Jurnal hukum Internasional. Vol. 5 No. 2. Januari 2008;

Iriansyah. "Pembayaran Dalam Transaksi Perdagangan Internasional". Jurnal Hukum Respublica. Vol. 3 No. 2. Pekanbaru: Universitas Lancang Kuning;

Raharjo, Sumarsono. "Pentingnya Perlindungan Hukum Informasi Elektronik dalam Transaksi Online". Justitia Et Pax. Vol. 26 No. 1. Juni 2006;

Setiawati, Wenny. "Elektronic Commerce in The International Trade and The Impact on Indonesia". Jurnal Hukum dan Pembangunan. Tahun ke-38 No. 3. Juli-September 2008. Jakarta: FH UI;

Tim Direktorat Hukum, "Diskusi Dengan Uncitral Dan "Electronic Evidence \& E-Discovery Forum". Buletin Hukum Perbankan Dan Kebanksentralan. Volume 5. Nomor 2. Agustus 2007.

Indra M Utoyo.2001. "Public Key", makalah, Seminar Nasional Cyber law "Infrastruktur dan Kebutuhan Dukungan Aspek Hukumnya dalam Implementasi Tandatangan Digital", SHTB Bandung, 9 April;

Simatupang, Taufik H. "Hukum dan Pembangunan Ekonomi”. Jurnal Ilmiah Kebijakan Hukum. Vol. 1 No. 1. April 2007;

Purwanto, Harry. "Keberadaan Asas Pacta Sunt Servanda Dalam Perjanjian Internasional". Jurnal Mimbar Hukum. Vol. 21 No. 1. Februari 2009. Yogyakarta: FH UGM. 
Pengaruh Perkembangan Teknologi Informasi Terhadap Keabsahan Perjanjian ... 67 